\title{
Implementation of innovative technologies for the improvement of concrete properties for freezing and thawing processes
}

\author{
Krzysztof FALKOWSKI*1 \\ ${ }^{1}$ Higher School of Agribusiness in Lomza, Łomża, Poland
}

\begin{abstract}
For over a hundred years, concrete has been a well-known building material and is widely used in construction. Its properties have convinced construction engineers, architects, contractors and investors, which is why it is currently difficult to find a building completed without the use of this material. However, the influence of atmospheric conditions and other environmental influences means that over time they leave more and more visible signs of progressive destruction even on the best building material of the century. Taking into account the problems related to aeration and surface hydrophobization, the aim of the work was to demonstrate that by using an admixture in the form of an anionic bitumen emulsion and a superplasticizer based on polycarboxylate ethers, it is possible to obtain hard-to-wet concretes with a favorable porosity structure and increased resistance to environmental influences. For static calculations and dimensioning, an original calculation model of the pavement made of concrete with dispersed reinforcement in the form of fibers was used, which made it possible to eliminate the reinforcement in the form of bars. Laboratory tests with the use of concrete samples taken during concreting carried out after 28 days of maturation confirmed the high compressive strength.
\end{abstract}

Keywords: construction, concrete, frost resistance

\section{Introduction}

One of the problems concrete structures face in winter conditions is damage caused by freezing and thawing. When the water-saturated concrete freezes, different pressures (hydraulic and osmotic) can build up in the pores of the cement slurry and aggregates. These pressures are magnified by the freezing of additional water that enters the porous structure as the temperature becomes positive. The alternating cycles of freezing and thawing can eventually lead to significant deterioration of the material in the form of cracks, chipping and superficial flaking, and consequently to the complete destruction of the element due to loss of weight and loss of strength. In this respect, Poland has the most severe climate in Europe, because concrete is damaged not only by negative temperatures, but mainly by cyclic freezing and thawing [1]. Therefore, the frost resistance of concrete in Polish projects is of particular importance.

Concrete resistance to cyclic freezing and thawing can be ensured by shaping the frost-resistant structure of the cement slurry as a result of air entrainment or by limiting concrete saturation with water, e.g. as a result of hydrophobization. According to the PN-EN 206 [26] standard, in frost corrosion conditions it is particularly recommended to reduce the $\mathrm{w} / \mathrm{c}$ and aerate the concrete. In practice, however, obtaining proper aeration takes place at the expense of reducing tightness and a significant decrease in strength (20-30\%) [3]. Adherence to the principles set out in the standard should be sufficient for the structure to survive the designed period of use without additional protective or repair measures. However, practice [5, 10, 11] shows that their fulfillment does not always ensure resistance in real conditions. On the other hand, the disadvantage of surface hydrophobization is its limited durability. In addition, it is not possible to make a perfectly tight coating on the entire surface of the concrete, as some places are not accessible, e.g. to the interior of expansion joints. Silanes and siloxides, which are used to perform hydrophobization, decompose and after approx. 7 years of direct exposure to sunlight, the surface loses its hydrophobic properties [6].

\footnotetext{
${ }^{*}$ Corresponding author: E-mail address: krzysztof.falkowski@wsa.edu.pl (Krzysztof FALKOWSKI)
} 
To achieve the assumed goal, a three-factor experiment with five levels of variability was planned and a statistical evaluation of the influence of the examined factors on the physical properties of the mixture and hardened concrete was performed [4]. Statistical analysis methods were also used to develop optimal concrete formulas with bitumen emulsion, which were implemented on a large scale in industrial conditions. The presented work presents the comprehensive construction of the surface of the maneuvering yard on the premises of the Innovative Multimodal Container Terminal at WOC near Terespol, during which [16]:

- for static calculations and dimensioning, the original calculation model of the pavement made of concrete with dispersed reinforcement in the form of fibers was used, which made it possible to eliminate the reinforcement in the form of bars;

- an innovative solution of the structural system was used with a concrete slab placed on a layer of mechanically stabilized crushed aggregate with the omission of base concrete, thanks to which it was not necessary to make a sliding layer;

- innovative formulas of concretes with bitumen emulsion admixture were implemented, allowing to reduce the absorption of concrete and increase frost resistance without reducing its strength, which is particularly important as the axle loads of container cranes are 10 times higher than allowed on EU roads.

A 5-stage implementation was adopted (Fig. 1) to enable the terminal to operate simultaneously on $3 / 5$ of the surface and work on $2 / 5$ of the surface ( $1 / 5$ of the surface - works, $1 / 5$ of the surface - care and maturation). In this way, the surface of the container terminal was made of concrete modified with bituminous emulsion with an area of $11076 m^{2}[2]$.

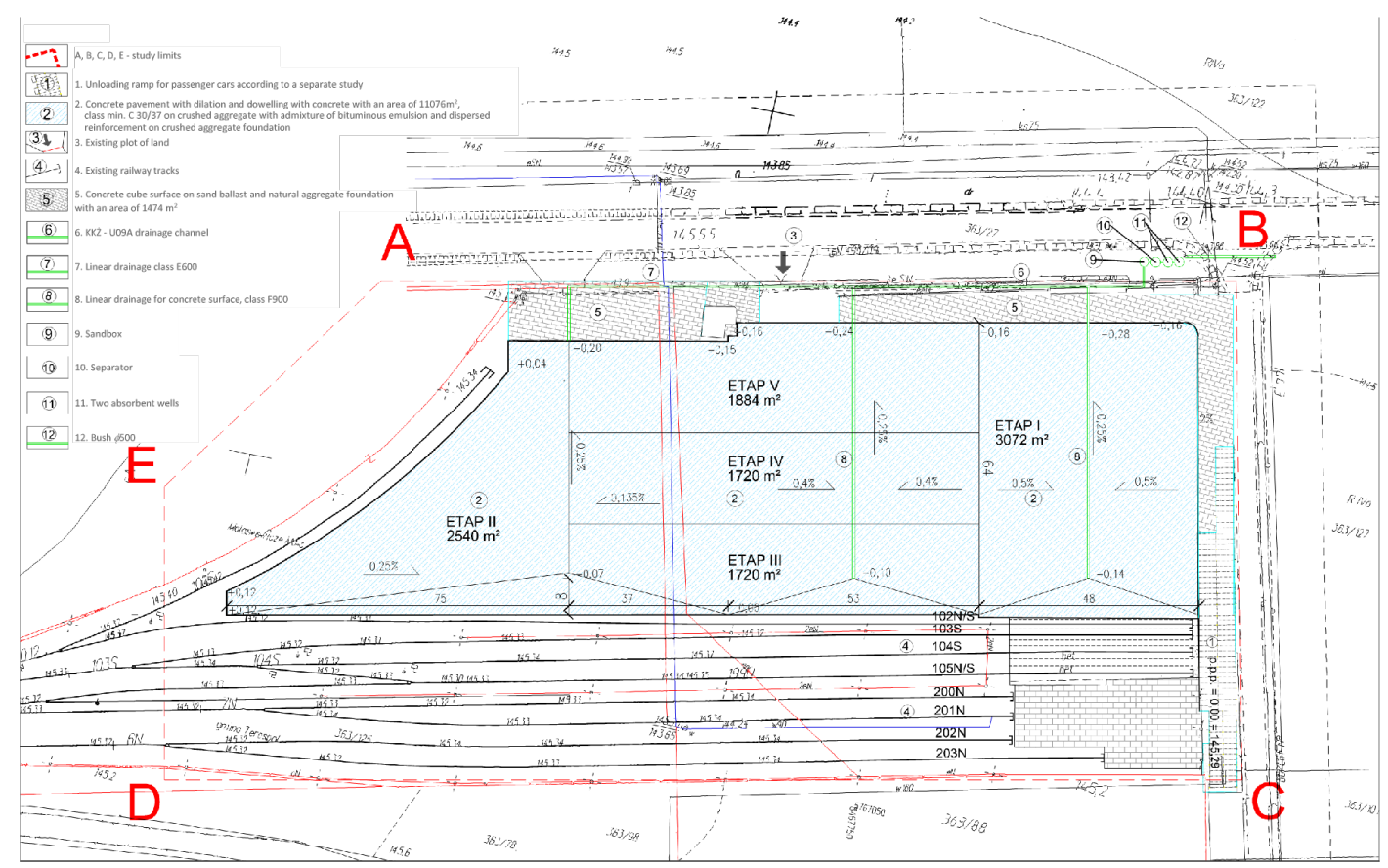

Figure 1. Staging of works on the implementation of the Innovative Multimodal Container Terminal

\section{Pavement construction}

When designing the surface structure of the terminal, the load from the container crane (Reach Stacker) model SC 4531 TA 5 was assumed. the tire exerts on the pavement $1.0 \mathrm{~N} / \mathrm{mm}^{2}(1 \mathrm{MPa})$. The front axle load is transferred to each of the 4 wheels, i.e. $101.5 \mathrm{t} / 4=25.375 \mathrm{t}(253750 \mathrm{~N})$. This load results from the dead weight of the Reach Stacker vehicle equal to $71.1 \mathrm{t}$ and the load of the container being lifted. In addition, loads from stacked 30-ton containers were taken into account. Based on the publication [13], a weight reduction factor was applied depending on the number of containers in a stack. The design weight of a stack with five containers $0.6 \times 5 \times 300 \mathrm{kN}=900.00$ $\mathrm{kN}$ was assumed, transferred to the pavement via four corner feet with dimensions of $162 \mathrm{x} 178 \mathrm{~mm}$, with a contact pressure of $7.8 \mathrm{~N} / \mathrm{mm}^{2}$. 
For the calculations, load patterns from wheeled cranes and stacks with containers in several variants, illustrated in Fig. 2, were adopted.

- for a single wheel $\mathrm{P}=253750 \mathrm{~N}$, contact pressure $\mathrm{p}=1.0 \mathrm{~N} / \mathrm{mm}^{2}$,

- for twin wheels with an axial distance $\mathrm{x}=560 \mathrm{~mm}, \mathrm{p}=1.0 \mathrm{~N} / \mathrm{mm}^{2}$,

- from a single stack of containers $\mathrm{P}=225000 \mathrm{~N}$ per $162 \times 178 \mathrm{~mm}$ foot,

- from 2 adjacent stacks of containers in a row with an axial distance $\mathrm{x}=162 \mathrm{~mm}$.

- from 4 adjacent stacks in two rows spaced $500 \mathrm{~mm}$ apart, axial distances $\mathrm{x}=162 \mathrm{~mm}, \mathrm{y}=678 \mathrm{~mm}$

a)

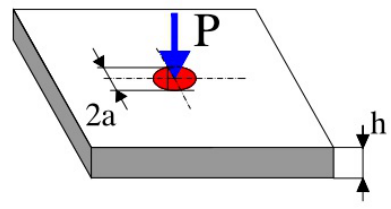

b)

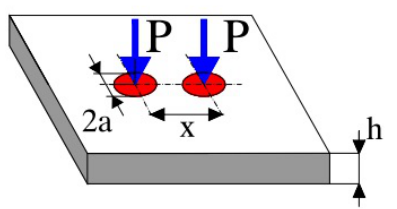

c)

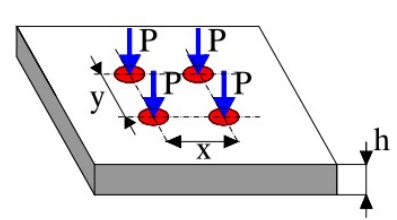

Figure 2. Load patterns adopted for the calculation of the pavement: a) from a single wheel/bead; b) from a two wheel/two feet; c) from a four feet

The preliminary calculations were based on the slab model developed by Westergaard, in which the concrete slab with the modulus of elasticity Ecm and Poisson's ratio v rests on a Winkler-type subsoil characterized by the subsoil reaction coefficient $\mathrm{k}[30]$.

Taking into account the recommendations of the PN-EN 206 [26]standard related to aggressive environmental impact, concrete pavements were classified as the most aggressive exposure class XF4 (cyclical freezing and thawing with de-icing agents), which required the use of minimum class C30 / 37 concrete. , with a cement content of at least $340 \mathrm{~kg} / \mathrm{m}^{3}$ with limitation of the amount of water $(\mathrm{w} / \mathrm{c} \leq 0.45)$.

For the calculations, a slab with a thickness of $\mathrm{h}=400 \mathrm{~mm}$ was adopted, based on a foundation characterized by elastic deformation modules: primary $E_{v 1} \geq 100$ and secondary $E_{v 2} \geq 180 \mathrm{MPa}$, while maintaining the ratio $E_{v 2} /$ $E_{v 1} \leq 2.2$. The foundation was mechanically compacted crushed aggregate placed on a layer stabilized with cement. Such a structure of the foundation allowed to verify its load capacity based on the actual measurements of the $E_{v 2}$ module made with the VSS apparatus. Moreover, unlike the concrete substructure, there was no risk of scratching onto the base plate. The concrete class C35 / 45 was assumed, for which the longitudinal modulus of elasticity calculated according to Eurocode 2 [25] was $34545 \mathrm{~N} / \mathrm{mm} 2$. The Poissons ratio v was assumed to be 0.15 . The subsoil reaction modulus $\mathrm{k}$ was determined according to TR 34 [32] from the dependence taking into account the values of the modulus of elastic deformation of the mechanically stabilized broken aggregate foundation $E_{v 1} \geq 100 \mathrm{MPa}$ and $E_{v 2} \geq 180 \mathrm{MPa}$. The diagram of the layer system is shown in Fig. 3.

The modulus of the substrate reaction was calculated from the formula [32]

$$
k=\frac{E_{v 2}}{550 \cdot E_{v 2} / E_{v 1}}=0.182 \mathrm{~N} / \mathrm{mm}^{3}
$$

Then, the radius of the relative stiffness of the plate 1 was calculated

$$
l=\sqrt[4]{\frac{E_{c m} \cdot h^{3}}{12 \cdot\left(1-v^{2}\right) \cdot k}}=1045 \mathrm{~mm}
$$

At the same time, for each load variant, the equivalent radii of the loading surfaces a and the equivalent radii $b$ were determined, taking into account the distribution of loads over the plate thickness h. Using the recommendations contained in the study [31], the equivalent radius calculated from formulas (3) was used to calculate the stresses from vehicle loads. , (4) and (5) at $\mathrm{a} \geq 1.25 \mathrm{~h}$ : 


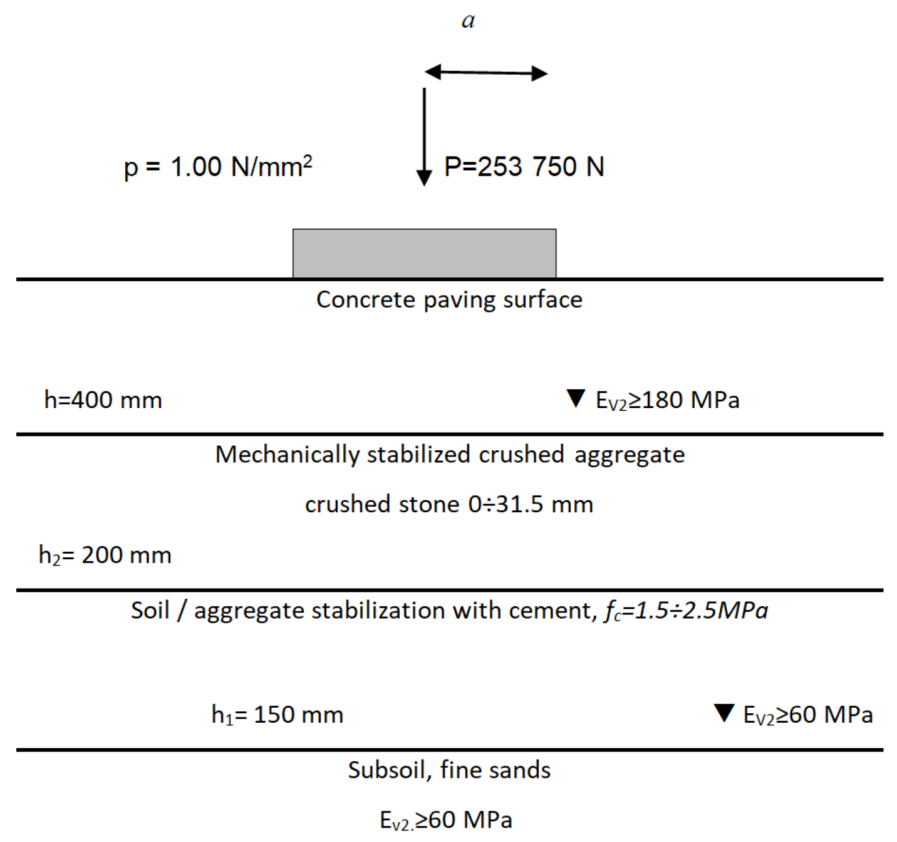

Figure 3. Scheme of the pavement construction layers

$$
\begin{gathered}
a=\sqrt{\frac{P}{\pi \cdot p}} \\
a=\sqrt{\frac{P}{\pi \cdot p}+0.6 \cdot h}
\end{gathered}
$$

where:

P - concentrated load exerted by the wheel,

p - contact pressure caused by a concentrated force acting on the plate (pressure in the wheel),

h - plate thickness.

On the other hand, for the calculation of stresses from loads with stacked containers, the equivalent radius of the support - container feet, calculated from the following formula [31] was adopted:

for $\mathrm{a} \geq 1.75 \cdot \mathrm{h}:$

$$
a=\sqrt{\frac{(\sqrt{A}+2.4 \cdot h)^{2}}{\pi}}
$$

where:

$\mathrm{h}$ - plate thickness,

A - container foot area.

for $\mathrm{a}<1.734 \cdot \mathrm{h}$ :

$$
b=\sqrt{\left(1.6 a^{2}+h^{2}\right)}-0.675 \cdot h
$$

for $\mathrm{a}>1.734 \cdot \mathrm{h}$ 


$$
b=a
$$

Using the equations of Westergaard, Kelley and Pickett [8, 30], the stresses from service loads in the form of concentrated forces were calculated

- in the center of the disc:

$$
\sigma_{P M}=\frac{0.275 \cdot P}{h^{2}} \cdot(1+v) \cdot\left[4 \ln \left(\frac{l}{b}\right)+1.069\right]
$$

- on the edge of the plate:

$$
\sigma_{P R}=\frac{0.529 \cdot P}{h^{2}} \cdot(1+0.54 v) \cdot\left[4 \ln \left(\frac{l}{b}\right)+\lg \left(\frac{b}{25.4}\right)\right]
$$

- in the corner of the plate:

$$
\sigma_{P E}=\frac{4.2 \cdot P}{h^{2}} \cdot\left[1-\frac{\sqrt{\frac{a}{l}}}{0.925+0.22 \cdot \frac{a}{l}}\right]
$$

The calculated values of equivalent radii of loading surfaces a and b as well as the components of stresses from

\begin{tabular}{|c|c|c|c|c|c|c|c|}
\hline \multicolumn{2}{|l|}{ load type } & \multicolumn{2}{|c|}{ mobile crane } & \multicolumn{4}{|c|}{ container stacks } \\
\hline & & $\begin{array}{c}\text { first } \\
\text { wheel }\end{array}$ & $\begin{array}{c}\text { second } \\
\text { wheel }\end{array}$ & 1 & 2 & 3 & 4 \\
\hline concentrated load & $P_{k}[\mathrm{~N}]$ & 253750 & 253750 & 225000 & 225000 & 225000 & 225000 \\
\hline contact pressure & $p\left[\mathrm{~N} / \mathrm{mm}^{2}\right]$ & 1.0 & 1.0 & 7.8 & 7.8 & 7.8 & 7.8 \\
\hline modulus of substrate reaction & $k\left[\mathrm{~N} / \mathrm{mm}^{3}\right]$ & \multicolumn{6}{|c|}{0.182} \\
\hline radius of relative stiffness & $l[\mathrm{~mm}]$ & \multicolumn{6}{|c|}{1045} \\
\hline spacing of concentrated forces & $s[\mathrm{~mm}]$ & & 560 & & 162 & 678 & 697 \\
\hline equivalent radius & $a[\mathrm{~mm}]$ & 524 & 524 & \multicolumn{4}{|c|}{638} \\
\hline equivalent radius & $b[\mathrm{~mm}]$ & 504 & 504 & \multicolumn{4}{|c|}{631} \\
\hline tension in the middle & $\sigma_{1}\left[\mathrm{~N} / \mathrm{mm}^{2}\right]$ & 1.17 & 0.63 & 0.87 & 0.72 & 0.30 & 0.28 \\
\hline edge stress & $\sigma_{2}\left[\mathrm{~N} / \mathrm{mm}^{2}\right]$ & 2.32 & 1.26 & 1.83 & 1.54 & 0.63 & 0.60 \\
\hline corner stress & $\sigma_{3}\left[\mathrm{~N} / \mathrm{mm}^{2}\right]$ & 2.10 & 1.14 & 1.55 & 1.31 & 0.54 & 0.52 \\
\hline
\end{tabular}
individual concentrated forces are presented in Table 1.

Table 1. Component stresses from concentrated loads as a result of the action of mobile cranes and stacked containers on the plate

Normal stress resulting from the shrinkage of the slab was calculated as a function of the friction parameter $\mu$, the distance between the welds $\mathrm{L}$ and the slab weight $\mathrm{g}$, from the following formula:

$$
\sigma_{s}=\frac{\mu L G}{2 h}=0.094 N / m^{2}
$$

where:

$\mathrm{L}=5000 \mathrm{~mm}-$ maximum distance between expansion joints,

$\mu=1.5$ - coefficient of friction between concrete and crushed aggregate foundation, 
$\mathrm{g}=0.01 \mathrm{~N} / \mathrm{mm}^{2}-$ plate weight.

The thermal stresses resulting from the temperature difference between the lower and upper surface of the slab were calculated based on the following relationships [8, 30]:

- in the center of the disc:

$$
\sigma_{\Delta t}^{1}=\frac{E_{c m(t)} \cdot \alpha_{t} \cdot \Delta t}{2} \cdot \frac{C_{x}+v \cdot C_{y}}{1-v^{2}}=1.09 \mathrm{~N} / \mathrm{mm}^{2}
$$

- on its edge:

$$
\sigma_{\Delta t}^{2}=\frac{E_{c m(t)} \cdot \alpha_{t} \cdot \Delta t}{2} \cdot C_{x}=0.90 N / m^{2}
$$

- in the corner of the plate:

$$
\sigma_{\Delta t}^{2}=\frac{E_{c m(t)} \cdot \alpha_{t} \cdot \Delta t}{3 \cdot\left(1-v^{2}\right)} \cdot \sqrt{\frac{a \cdot \sqrt{2}}{l}}=0.73 \mathrm{~N} / \mathrm{mm}^{2}
$$

where:

$E_{c m(t)}$ - modulus of elasticity of concrete from temperature changes, $E_{c m(t)}=(0.75 \div 0.85) E_{c m}[8]$,

For the calculations, $E_{c m(t)}=26,000 \mathrm{~N} / \mathrm{mm}^{2}$,

$\alpha_{t}$ - concrete thermal expansion coefficient equal to $10^{-5}[1 / \mathrm{K}],(0.01[\mathrm{~mm} / \mathrm{m} \cdot K][7])$,

$\Delta \mathrm{t}$ - temperature difference equal to $10 \mathrm{~K}$ as for external surfaces exposed to weather conditions [8, 14, 32].

The total bending tensile stresses were calculated taking into account the combination of concentrated force loads, the friction caused by shrinkage and the temperature difference between the lower and upper surface of the slab. The results are presented in Table 2 . The maximum stress in the center of the slab was obtained for a combination of loads with the action of four concentrated forces from adjacent stacks of containers. They amounted respectively:

- in the center of the disc $\sigma_{f l, s u m}^{1 \max }=4.19 \mathrm{~N} / \mathrm{mm}^{2}$

- on the edge $\sigma_{f l, \text { sum }}^{2 \max }=4.93 \mathrm{~N} / \mathrm{mm}^{2}$

- in the corner $\sigma_{f l, s u m}^{3 \max }=4.18 \mathrm{~N} / \mathrm{mm}^{2}$

\begin{tabular}{|c|c|c|c|c|c|c|c|c|c|}
\hline & \multicolumn{3}{|c|}{ Safety factors } & \multicolumn{2}{|c|}{$\begin{array}{c}\text { Correction } \\
\text { factors }\end{array}$} & \multicolumn{3}{|c|}{ Correction factors } & \multirow{2}{*}{$\begin{array}{c}\begin{array}{c}\text { Summary } \\
\text { stresses }\end{array} \\
\sigma_{\text {sum }}\left[\mathrm{N} / \mathrm{mm}^{2}\right. \\
\end{array}$} \\
\hline & $\gamma_{f Q}$ & $\gamma_{f s}$ & $\gamma_{f \Delta t}$ & $K_{Q}$ & $K_{\Delta t}$ & $\sigma_{P}\left[N / m m^{2}\right]$ & $\sigma_{s}\left[N / m m^{2}\right]$ & $\sigma_{\Delta t}\left[N / m m^{2}\right]$ & \\
\hline & \multicolumn{9}{|c|}{ Mobile crane SC 4531 TA 5} \\
\hline$\sigma^{1}-$ middle & 1.6 & 1.1 & 1.1 & 1.0 & 0.7 & 1.80 & 0.09 & 1.09 & 3.82 \\
\hline$\sigma^{2}$ - edge & 1.6 & 1.1 & 1.1 & 0.6 & 0.7 & 3.58 & 0.09 & 0.90 & 4.23 \\
\hline \multirow[t]{2}{*}{$\sigma^{3}-$ corner } & 1.6 & 1.1 & 1.1 & 0.6 & 0.7 & 3.24 & 0.09 & 0.72 & 3.76 \\
\hline & \multicolumn{9}{|c|}{ Container stacks in rows with spacing $50 \mathrm{~cm}$} \\
\hline$\sigma^{1}$ - middle & 1.5 & 1.1 & 1.1 & 1.0 & 0.7 & 2.17 & 0.09 & 1.09 & 4.19 \\
\hline$\sigma^{2}$ - edge & 1.5 & 1.1 & 1.1 & 0.6 & 0.7 & 4.60 & 0.09 & 0.90 & 4.93 \\
\hline$\sigma^{3}-$ corner & 1.5 & 1.1 & 1.1 & 0.6 & 0.7 & 3.92 & 0.09 & 0.72 & 4.18 \\
\hline
\end{tabular}

Table 2. Summary stresses from the combination of concentrated force loads, shrinkage friction and temperature difference 
When calculating the maximum tensile stresses for load combinations, the safety factors were adopted in accordance with TR 34 [32], ie 1.6 for the dynamic action (mobile cranes) and 1.5 for the static action (stacks with containers). Moreover, when calculating the stresses from service loads on the edge and corner of the slab, a reduction factor of 0.6 was used due to the use of dowels enabling the transfer of loads at the joint location and a factor of 0.7 for thermal stresses due to the limitation of warping of the slabs due to the lack of expansion slits [8,31].

In order to redistribute loads in the places of expansion joints, dowels made of St3S steel with a diameter of 40 $\mathrm{mm}$ and a spacing of $400 \mathrm{~mm}$ were used. The dowel length was assumed to be equal to the calculated effective length of $2 \times 8$ d, $2 \times 8 \times 40 \mathrm{~mm}=640 \mathrm{~mm}$. The spacing was checked assuming the stress transfer through dowels at full load capacity within 0.9 of the radius of relative stiffness of the slab on both sides of the load [32].

Then, in each case, i.e. in the center, edge and corner of the slab, the following condition was checked:

$$
\sigma_{f l, \text { sum }} \leq f_{f l, \text { dop.beton }}=\frac{5.5}{1.2}=4.58 \mathrm{~N} / \mathrm{mm}^{2}
$$

Maximum total stress from the combination of crane wheel loads, friction and the temperature did not exceed the allowable bending stresses transferred by the concrete taking into account the safety factor. Stresses from a single stack of containers and thermal influences also did not exceed the permissible stresses, while considering the arrangement of the stacks touching in two rows, it was found that the stresses at the edge were exceeded $(4.93 \mathrm{~N}$ $\left./ \mathrm{mm}^{2}\right)$. Therefore, a solution was adopted with a dispersed reinforcement in the form of synthetic fibers $54 \mathrm{~mm}$ long in the amount of $2 \mathrm{~kg} / \mathrm{m}^{3}$. Based on the data of the fiber manufacturer [9], taking into account the assumed concrete class as well as the type and quantity of fibers, the equivalent strength index $R_{e, 3}=0.30$, was adopted based on the JCI-SF4 standard [12]. This allowed the use of the plastic model to calculate the allowable stresses and thus increase the allowable bending tensile strength. Based on the Meyerhof-Losberg theory [32], the allowable bending tensile strength of fibrobeton was assumed to be equal to the product of the conventional tensile bending strength of concrete and the coefficient taking into account the favorable effect of fibers:

$$
f_{f l, \text { dop.firbrobeton }}=f_{c t m, f l}\left(1+R_{e, 3}\right)=7.15 \mathrm{~N} / \mathrm{mm}^{2}
$$

where:

$R_{e, 3}$ - equivalent strength index characterizing fibrobeton [7],

$f_{c t m, f l}=5.50 \mathrm{~N} / \mathrm{mm}^{2}-$ conventional average tensile strength for bending concrete C35/45 [7].

\section{Surface realization}

The system of construction layers presented in Fig. 4 was adopted for implementation.

The existing substrate, in the form of fine, medium-compacted sands (insensitive to frost and water), granulated and compacted mechanically so that it has the compaction index Is $\geq 1.00$, primary and secondary deformation modules $E_{v 1} \geq 60 \mathrm{MPa}, E_{v 2} \geq 120 \mathrm{MPa}$, and the deformation index $I_{o}=E_{v 2} / E_{v 1} \leq 2.2$ [28]. Measurements were made with a VSS probe. Due to the heterogeneous measurement results, $15 \mathrm{~cm}$ cement stabilization with compressive strength was applied after 7 days of maturation $f_{c m, 7}=1.0 \div 1.6 \mathrm{MPa}$, and after 28 days of maturation $f_{c m, 28}=1.5 \div 2.5 \mathrm{MPa}$ [29]. The main foundation was made of mechanically stabilized crushed aggregate (Fig. 5). For fresh stabilization, a layer of crushed stone with a fraction of $0 \div 31.5 \mathrm{~mm}$ was laid and compacted with the use of heavy rubber rollers. After seven days, the tested deformation modules with reserve fulfilled the assumed requirements of $E_{v 1} \geq 100 M P a$, $E_{v 2} \geq 180 \mathrm{MPa}, E_{v 2} / E_{v 1} \leq 2.2$. Determination of the deformation modules of the foundation was carried out with a VSS probe in accordance with Annex to the PN-ENS-02205 standard [27].

A class F 900 linear drainage system in the form of prefabricated concrete troughs and a coalescence separator with a settling tank and a by-pass have been designed to drain rainwater. The surface was made with slight slopes, not exceeding $0.5 \%$, enabling rainwater to run off into the channels and safe maneuvering and stacking of the containers. The assembly of prefabricated elements on a concrete bench is shown in Fig. 6.

On the basis of laboratory tests, three concrete compositions with $\mathrm{w} / \mathrm{c}=0.35$ were specified for the execution of the concrete pavement (Table 3). The compositions were selected due to the availability and prices of ingredients, as 


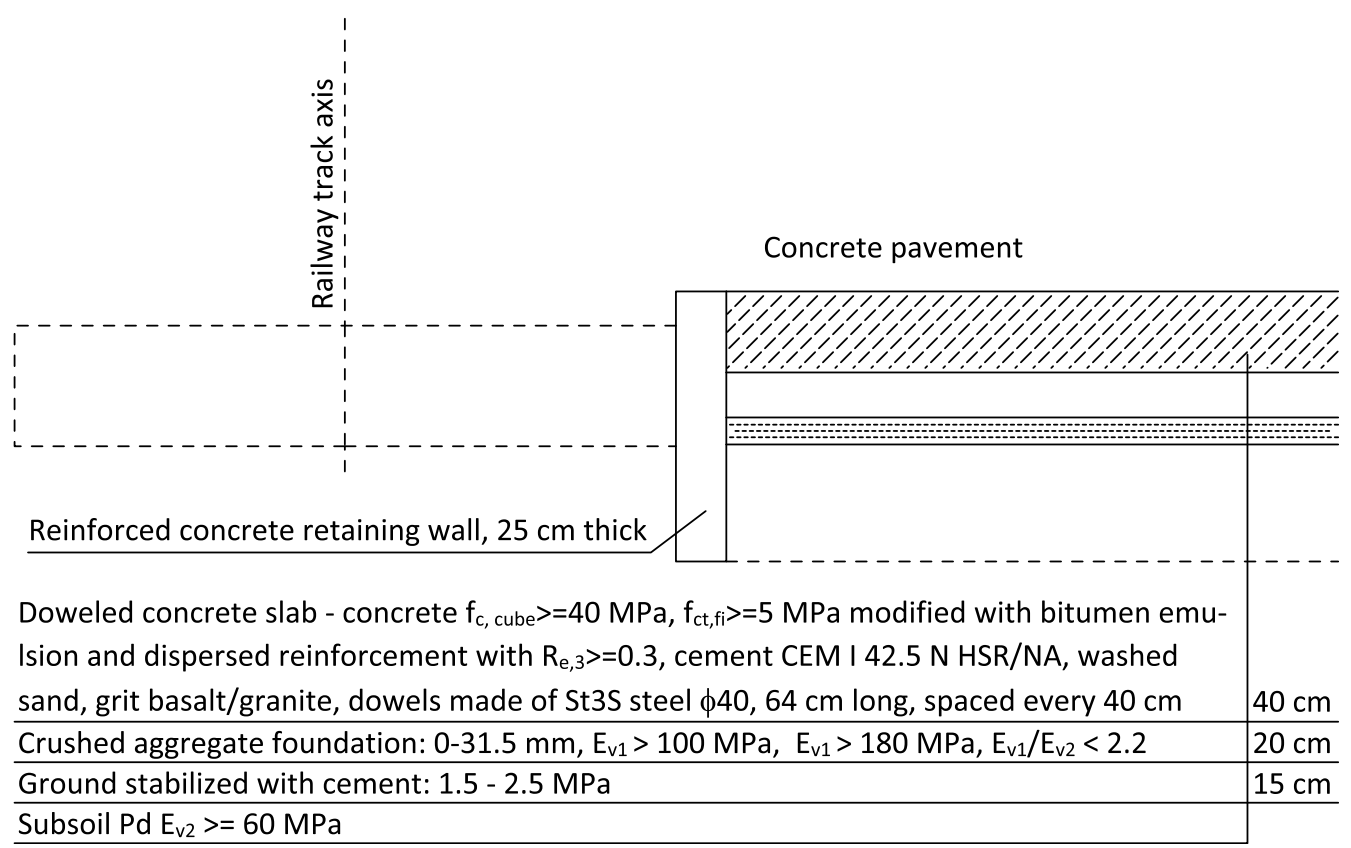

Figure 4. Cross-section of the pavement structure on the base of crushed aggregate

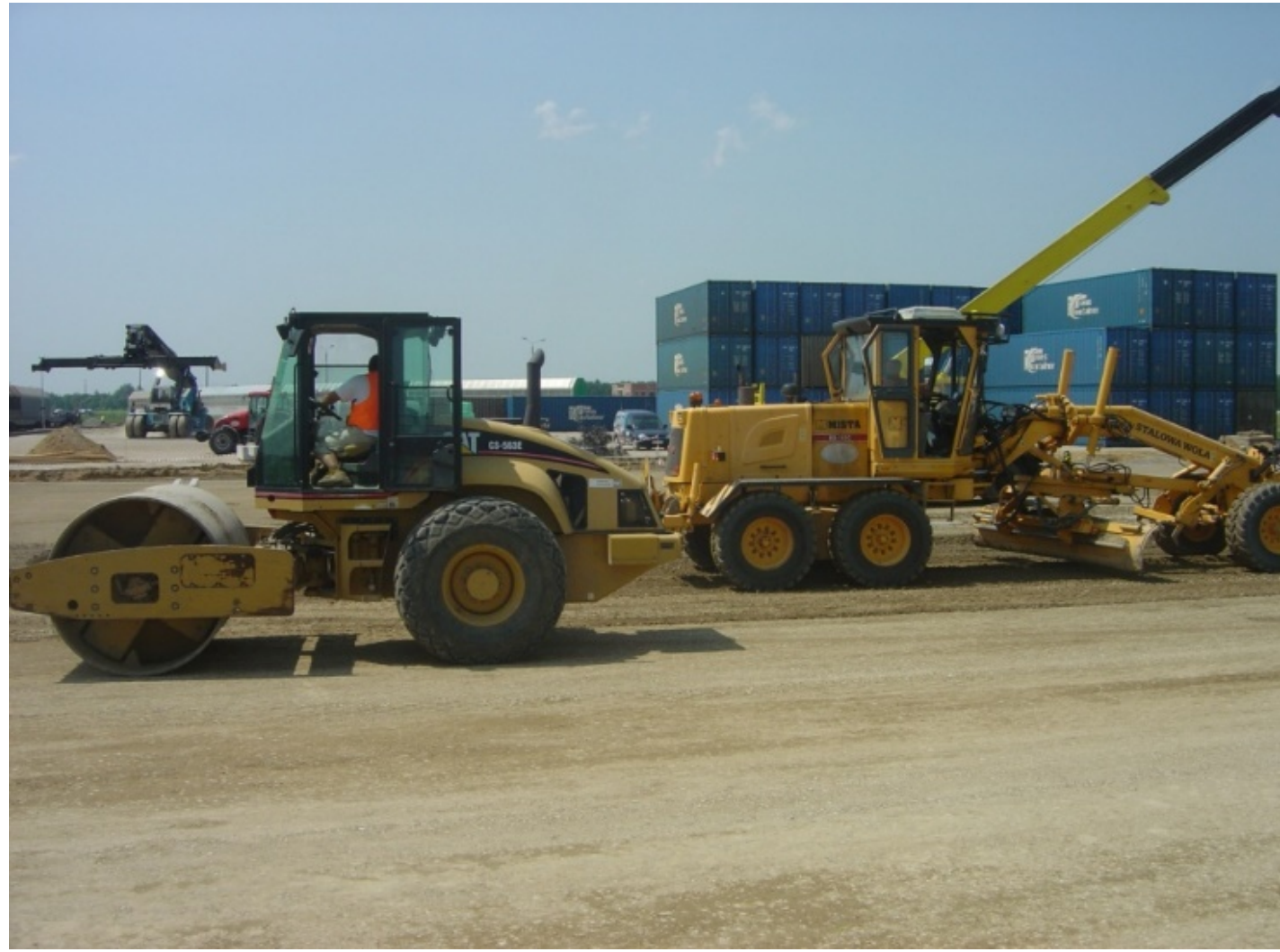

Figure 5. The main foundation is made of mechanically stabilized crushed aggregate

well as the value of the average daily temperature during the pavement construction and the place of incorporation into the structure.

The consistency was checked each time at the construction site before laying the concrete mix. The mixture was characterized by a homogeneous consistency of K4 (cone slump $\mathrm{S} \leq 110 \mathrm{~mm}$ ). For design reasons and in order to 


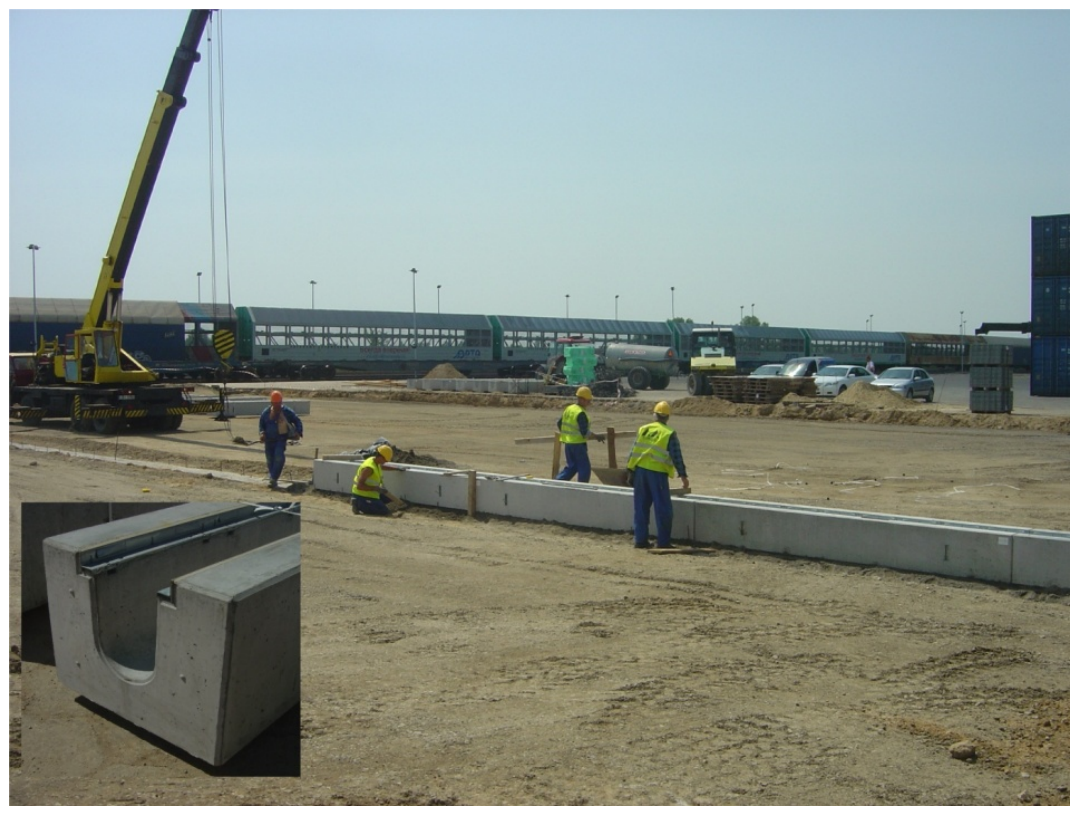

Figure 6. Linear drainage class F 900 made of prefabricated concrete channels

Table 3. Specification of the three compositions of the recipe concrete with $\mathrm{w} / \mathrm{c}=0.35$ used on the surface of the Innovative Multimodal Reloading Terminal near Terespol

\begin{tabular}{|c|c|c|c|c|c|c|c|c|c|c|}
\hline \multirow{3}{*}{ composition } & \multicolumn{10}{|c|}{ The amount of ingredients, $\mathrm{kg} / \mathrm{m}^{3}$} \\
\hline & \multirow[b]{2}{*}{ cement } & \multirow[b]{2}{*}{ emulsion } & \multicolumn{2}{|c|}{ admixtures } & \multirow{2}{*}{$\begin{array}{l}\text { sand } \\
\text { rinsed }\end{array}$} & \multicolumn{2}{|c|}{ basalt grits } & \multicolumn{2}{|c|}{ granite grits } & \multirow[b]{2}{*}{ water } \\
\hline & & & liquefying & accelerating & & $\begin{array}{l}2 \div 8 \\
\mathrm{~mm}\end{array}$ & $\begin{array}{c}8 \div 16 \\
\mathrm{~mm}\end{array}$ & $\begin{array}{l}2 \div 8 \\
\mathrm{~mm}\end{array}$ & $\begin{array}{c}8 \div 16 \\
\mathrm{~mm}\end{array}$ & \\
\hline $\mathrm{CC} 1-\mathrm{E}$ & \multirow{3}{*}{360} & \multirow{3}{*}{6.66} & $3.15^{1)} / 2.45^{2)}$ & - & 690 & 488 & 728 & & & \multirow{3}{*}{125} \\
\hline $\mathrm{CC} 2-\mathrm{E}$ & & & $3.15^{1)} / 2.45^{2)}$ & - & 649 & & & 464 & 743 & \\
\hline CC3-E & & & $3.85^{3)} / 0$ & $2.1^{4)}$ & 665 & & & 506 & 702 & \\
\hline $\begin{array}{l}\text { 1) plasticizer } \\
\text { 2) superplast } \\
\text { 3) superplast } \\
\text { 4) chloride-fr }\end{array}$ & $\begin{array}{l}\text { ased on l } \\
\text { zer basec } \\
\text { zer that } \\
\text { admixtu }\end{array}$ & $\begin{array}{l}\text { agosulfonat } \\
\text { on polycar } \\
\text { an be re-d } \\
\text { e accelerat }\end{array}$ & $\begin{array}{l}\text { oxylene ether } \\
\text { sed at the cons } \\
\text { ag hardening }\end{array}$ & $\begin{array}{l}\text { uction site } \\
\text { ed on calciu }\end{array}$ & itrote & & & & & \\
\hline
\end{tabular}

eliminate shrinkage cracks, $54 \mathrm{~mm}$ long synthetic fiber dispersed reinforcement was used, with an equivalent strength index (resistance to cracking) $R_{e, 3}=0.3$ [18]. In order to improve the cooperation of the plates at the gaps and to reduce keying, dowels made of St3S steel were used in the middle of the plate thickness, spaced every $40 \mathrm{~cm}$, which met the recommendations contained in the standard [23] (Fig. 7). The dowel diameter was $40 \mathrm{~mm}$ and the length was $640 \mathrm{~mm}$. In accordance with the standard [24], the dowels were half covered with a bituminous coating, preventing them from bonding with the concrete to one of the plates, and placed on racks made of 6 mm diameter St3S steel rods.

The intervals between expansion joints did not exceed $5 \mathrm{~m}$. The first $3 \mathrm{~mm}$ wide cut on $1 / 3$ of the board thickness was made, depending on the temperature, from 12 to 24 hours after concreting. The widening of the joints to a minimum of $8 \mathrm{~mm}$ and a minimum depth of $8 \mathrm{~mm}$ was made after 28 days of concrete maturation. The edges of the slots were chamfered $(3 \times 3 \mathrm{~mm})$. A sealing cord made of synthetic material was used in the expansion joints. The gaps were filled with a permanently elastic two-component polymer-based sealing compound, resistant to de-icing agents, fuels and automotive oils. Before filling, the joints were carefully cleaned and primed.

The upper surface of the freshly laid and vibrated concrete mix was mechanically floated, and then treatments 


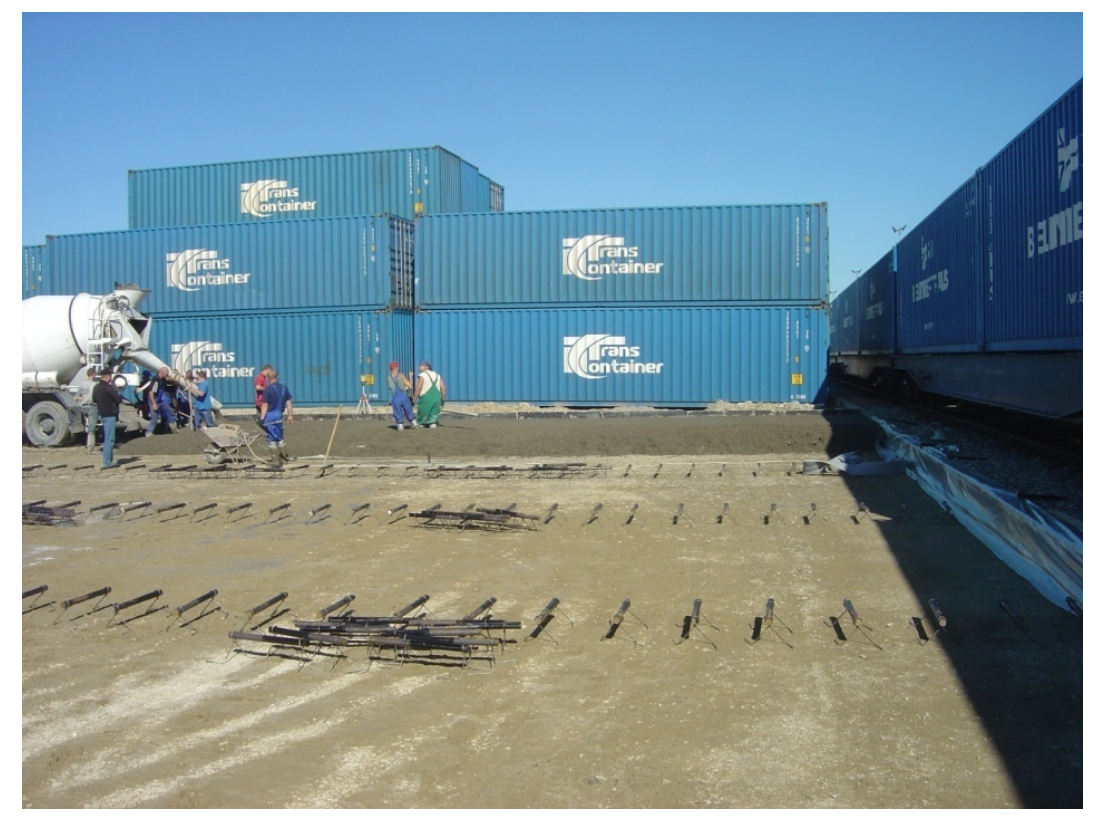

Figure 7. The arrangement of dowels during concreting

were carried out to give the surface appropriate roughness by brushing in the transverse direction - which will ensure faster water drainage (Fig. 8). Then the concrete was systematically sprinkled with water through the geotextile placed on it. The care period was 21 days. The pavement was put to use 28 days after concreting. Figure 9 shows the stacking of containers.

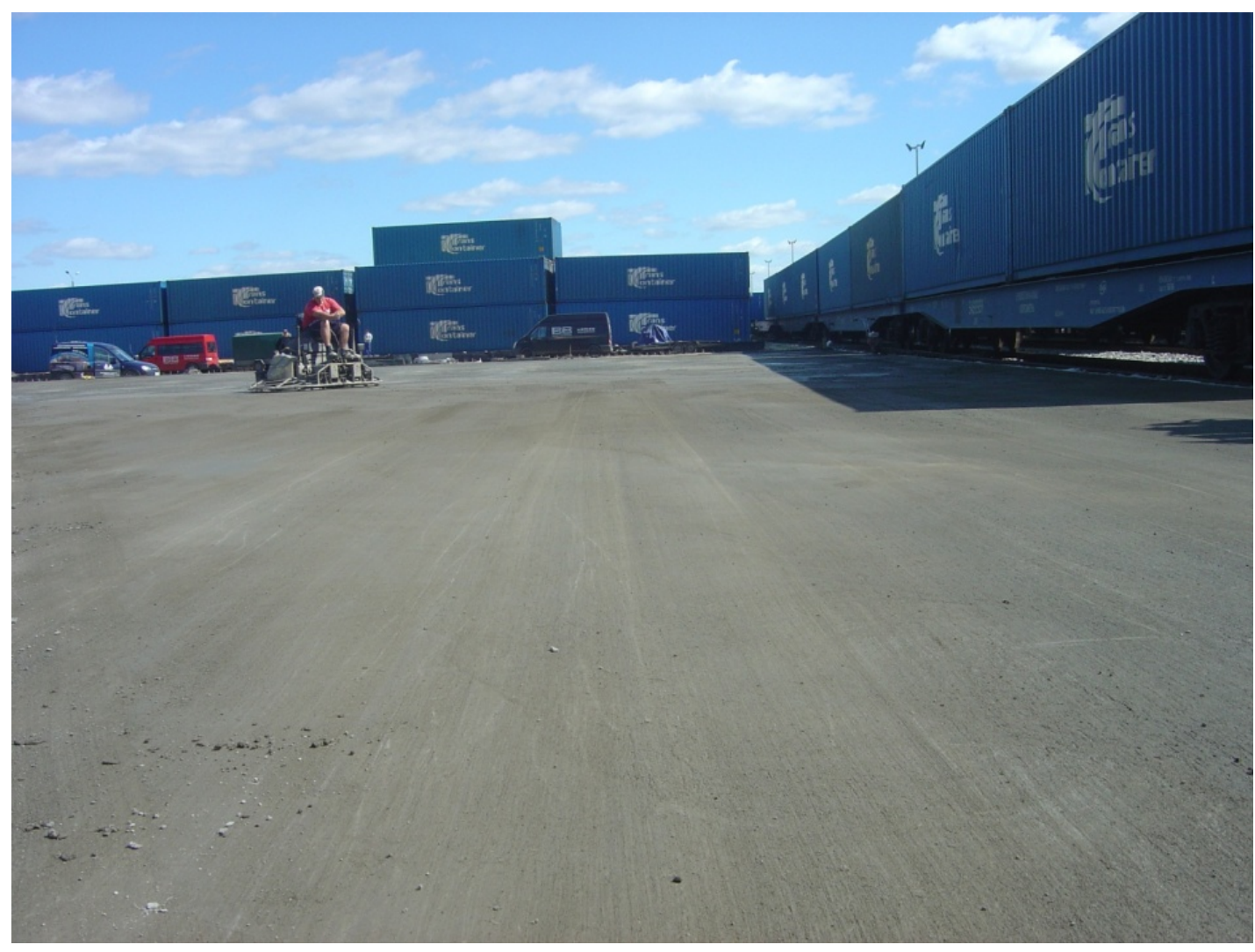

Figure 8. Floating and texturing of concrete pavements 


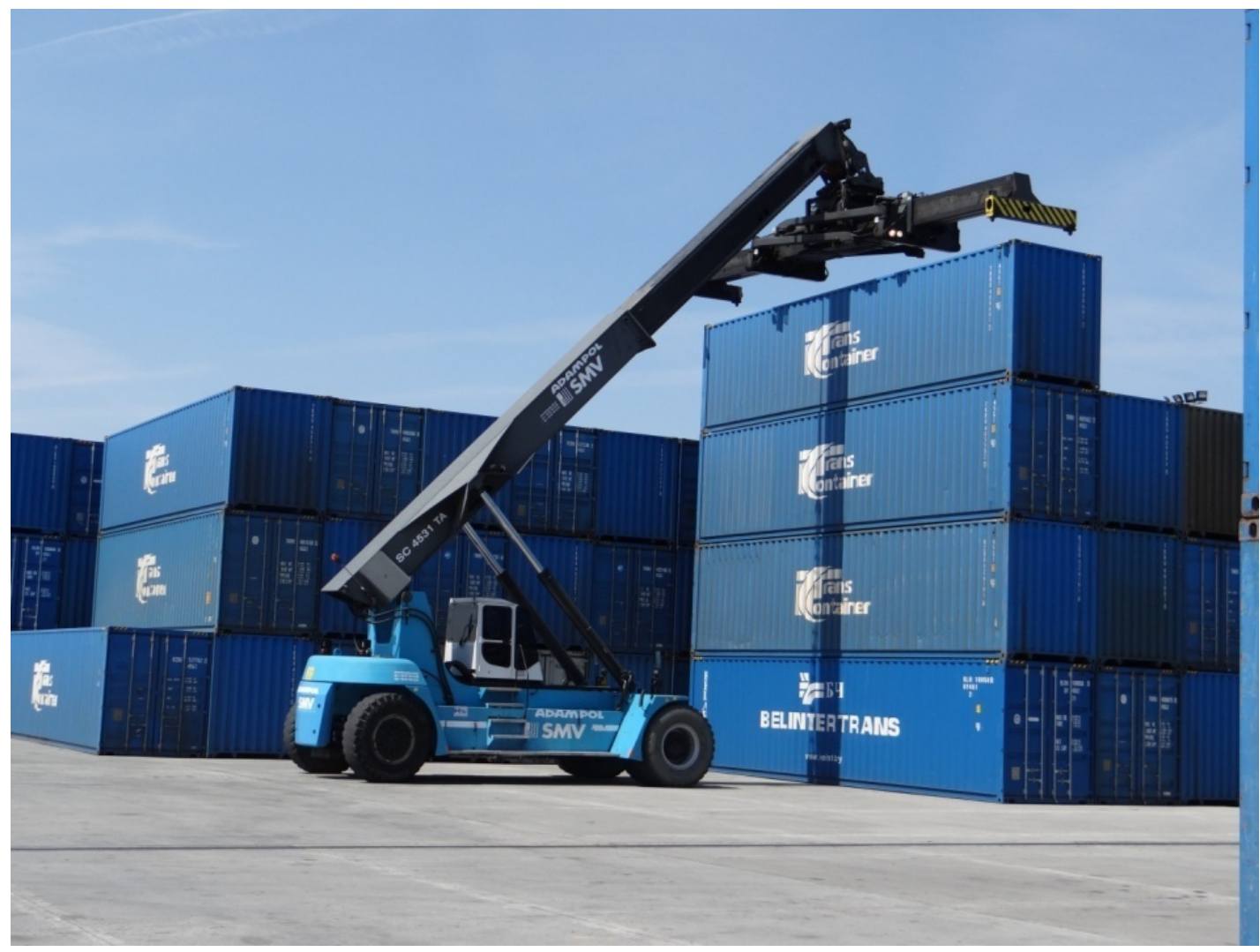

Figure 9. Storing containers in stacks. Photo Author

\section{Conclusions}

Laboratory tests with the use of concrete samples taken during concreting carried out after 28 days of maturation confirmed the high compressive strength $f_{c m, 28}=49.74 \div 58.20 \mathrm{MPa}$ and tensile strength $f_{c t m, f l}=5.55 \div 5.72 \mathrm{MPa}$ (in two-point load system). High frost resistance was found F200 according to [18] and FT2 according to [17, 23] and low water permeability (penetration depth $<30 \mathrm{~mm}$ ) [23], and reduced water absorption to $3.62 \%$ as a result of the use of bituminous admixture. The average depth of water penetration at a pressure of $0.8 \mathrm{MPa}$ for concrete with granite grit was $14.33 \mathrm{~mm}$, and the maximum was $26 \mathrm{~mm}$. However, for the composition with basalt grits, these values were slightly lower and amounted to $13.1 \mathrm{~mm}$ and $25 \mathrm{~mm}$, respectively. The test methods and results are listed in Table 4 .

Table 4. Test results for cement composites modified with bituminous emulsion in industrial conditions

\begin{tabular}{|c|c|c|c|}
\hline Lp. & Properties tested & Results & Test method \\
\hline 1. & $\begin{array}{c}\text { Compressive strength class according to } \\
\text { PN-EN 206-1 [128], not lower than: }\end{array}$ & C35/45 & PN-EN 12390-3 [19] \\
\hline 2. & Bending tensile strength [MPa] & $5.55 \div 5.72$ & PN-EN 12390-5 [20] \\
\hline 3. & $\begin{array}{c}\text { Frost resistance category according to } \\
\text { PN-EN 13877-2 [115] }\end{array}$ & FT2 & PKN-CEN/TS 12390-9 [17] \\
\hline 4. & Water absorption by weight [\%] & 3.62 & PN-B-06250 [18] \\
\hline 5. & Water penetration resistance [mm] & 26 mm & PN-EN 12390-8 [21] \\
\hline 6. & $\begin{array}{c}\text { Frost resistance when tested } \\
\text { by the direct method }\end{array}$ & F 200 & PN-B-06250 [18] \\
\hline
\end{tabular}

Moreover, the abrasion measurement performed on the Böhme disc showed higher resistance abrasion of cement composite modified with bituminous emulsion compared to concrete with air-entraining admixture by more than $5 \%$. The test was carried out on samples cut from boreholes made in the surface of the container yard in the case of concrete 
with emulsion and from cubic cubes in the case of air-entrained concrete, in accordance with the requirements of the regulations $[12,15,26]$. Additional bending tensile strength tests after 90 days gave a particularly satisfactory average result $7,21 \mathrm{MPa}$.

The concrete tests carried out confirmed that a cement composite of minimum class C35 / 45 was obtained, meeting the requirements for concrete used in the most severe exposure classes XF4, XD3, XC4, XA3, XM3 included in the PN-EN 206 standard [26] and functional requirements for pavement concrete [15, 22, 23].

The 11,076 $\mathrm{m}^{2}$ concrete pavement made of concrete modified with bituminous emulsion as described above is used as a maneuvering and storage yard and transfers the assumed loads from container cranes and stacked containers with a weight of up to 120 tons.

\section{References}

1. Bajorek, G. \& Gruszczyński, M. Konieczność doświadczalnej weryfikacji mrozoodporności betonu. Materiały Budowlane 6, 234 (2016).

2. Bołtryk, M., Pawluczuk, E. \& Falkowski, K. A report on the fabrication of concrete pavement with the application of anionic bitumen emulsion. Construction and Building Materials 154, 1004-1014 (2017).

3. Czarnecki, L. Beton według normy PN-EN 206-1. Polski Cement (2004).

4. Falkowski, K. cementowe modyfikowane emulsją bitumiczną. Materiały Budowlane 12, 45-49 (2014).

5. Flaga, K. O mrozoodporności betonów mostowych. Trwałość obiektów mostowych, 499-511 (2012).

6. Germaniuk, K. \& Gajda, T. Znaczenie hydrofobizacji w ochronie betonowych konstrukcji mostowych. Materiały Budowlane 11 (86-88 2013).

7. Glinicki, M. Beton ze zbrojeniem strukturalnym in. XXV Ogólnopolskie Warsztaty Projektanta Konstrukcji. 1 vols. (2010), 279-308.

8. Hajduk, P. Projektowanie podłóg przemysłowych (PWN, Warszawa, 2013).

9. Informacja techniczna RXF 54 - syntetyczne włókno konstrukcyjne. RUREDIL

10. Jasiczak, J., Ślosarczyk, A. \& Wołowicki, W. Przypadki braku mrozoodporności betonu w nowych wiaduktach drogowych wykonanych w latach 2002-2012 in. VIII Konferencja Dni Betonu (Wisła, 2014), 871-880.

11. Jawański, W. Struktura napowietrzenia mieszanki betonowej i betonu stwardniałego a jego rzeczywista mrozoodporność in. VIII Konferencja Dni Betonu (Wisła, 2014), 871-880.

12. JCI-SF4 Method of tests for flexural strength toughness of steel fiber reinforced concrete. Concrete library of JSCE. 3

13. Judycki, J. Projektowanie nawierzchni typu ciężkiego w portach i terminalach. Inżynieria Morska i Geotechnika 3, 277-282 (2005).

14. Katalog typowych konstrukcji nawierzchni podatnych i pótsztywnych (GDDKiA, 2014).

15. Ogólne Specyfikacje Techniczne 06.01 Nawierzchnie z betonu cementowego. GDDKiA

16. Ogólne Specyfikacje Techniczne M-13.01.00 Beton konstrukcyjny w obiekcie mostowym. GDDKiA

17. PKN-CEN/TS 12390-9:2007 Badanie stwardniałego betonu-Część 9. Odporność na zamrażanie/rozmrażanie ztuszczenie

18. PN-B-06250:1988 Beton zwykty

19. PN-EN 12390-3:2011 Badania betonu - Część 3: Wytrzymałość na ściskanie próbek do badań

20. PN-EN 12390-5:2011 Badania betonu - Część 5: Wytrzymałość na zginanie próbek do badań

21. PN-EN 12390-8:2011 Badania betonu - Część 8: Gtębokość penetracji wody pod ciśnieniem

22. PN-EN 13877-1 2007 Nawierzchnie betonowe.Część 1 Materiały

23. PN-EN 13877-2:2007 Nawierzchnie betonowe Część 2: Wymagania funkcjonalne dla nawierzchni betonowych

24. PN-EN 13877-3 Nawierzchnie betonowe. Część 3: Wymagania dla dybli stosowanych w nawierzchniach drogowych betonowych

25. PN-EN 1992-1-1:2008 Eurokod 2:Projektowanie konstrukcji z betonu.Część 1-1 Reguty ogólne i reguły dla budynków

26. PN-EN 206-1:2014 Beton - Część 1: Wymagania, właściwości, produkcja i zgodność

27. PN-EN-S-02205:1998. Drogi samochodowe - Roboty ziemne - Wymagania i badania

28. PN-S-06102:1997 Drogi samochodowe - Podbudowy z kruszyw stabilizowanych mechanicznie

29. PN-S-96012:1997 Drogi samochodowe - Podbudowa i ulepszone podłoże z gruntu stabilizowanego cementem

30. Szydło, A. Nawierzchnie drogowe z betonu cementowego. Teoria, wymiarowanie, realizacja. Polski Cement (2004).

31. Tejchman, J. \& Małasiewicz, A. Posadzki przemysłowe (Wydawnictwo Politechniki Gdańskiej, Gdańsk, 2006). 
32. TR 34 Technical Report No 34. Concrete Industrial Ground Floors - A guide to their Design and Construction. 2003. wyd. 3 